Ethos: Jurnal Penelitian dan Pengabdian kepada Masyarakat, Vol 8, No.2, Juni 2020: 205-211

\title{
Pelatihan Penggunaan Fasilitas Google dalam Kegiatan Pembelajaran untuk Meningkatkan Kompetensi PedagogiK
}

\author{
${ }^{1}$ Syamsul Bahri, ${ }^{2}$ Merta Simbolon, ${ }^{3}$ Desy Kumala Sari, ${ }^{4}$ Abrahan Laurens Rettob \\ 1,2,3,4 Universitas Musamus, Merauke, Papua, Indonesia. \\ email: ${ }^{1}$ syamsul_fkip@unmus.ac.id, ${ }^{2}$ simbolon_fkip@unmus.ac.id, sari_fkip@unmus.ac.id, \\ abraham_fkip@unmus.ac.id
}

\begin{abstract}
The ability to use information technology is an important ability in 21st century learning. This Community Service Activities (PKM) aims to conduct training and describing the pedagogical competency profile of teachers in SMK Negeri 1 Sota in utilizing information technology to support teaching and learning activities. The method used was training, mentoring, and evaluating the results of activities. The instrument used to obtain data after the training was a Likert scale questionnaire consisting of 3 aspects and distributed into 30 statements. The three aspects measured are the ability to use various information technology applications, the ability to utilize online learning media, and the ability to use search engines and data collectors. The data obtained were analyzed quantitatively and the results were categorized based on ideal standard deviations. The results obtained in this activity were the ability of teachers in SMK 1 Sota in utilizing information technology to support the learning process is still low.

Keywords: online learning media, pedagogical ability, google classroom, google form
\end{abstract}

\begin{abstract}
Abstrak. Kemampuan memanfaatkan teknologi informasi (TI) dalam pembelajaran merupakan kemampuan yang penting dalam pembelajaran abad 21. Kegiatan Pengabdian Kepada Masyarakat (PKM) ini bertujuan untuk memberikan pelatihan dan mendeskripsikan profil kompetensi pedagogik guru di SMK Negeri 1 Sota dalam memanfaatkan TI untuk mendukung kegiatan belajar mengajar. Metode yang digunakan dalam kegiatan ini adalah pelatihan, pendampingan, serta evaluasi hasil kegiatan. Instrumen yang digunakan untuk memperoleh data setelah dilakukan pelatihan adalah angket dengan skala likert yang terdiri dari 3 aspek dan dijabarkan menjadi 30 pernyataan. Ketiga aspek yang diukur adalah kemampuan menggunakan berbagai aplikasi TI kemampuan dalam memanfaatkan media pembelajaran online, dan kemampuan dalam menggunakan mesin pencari dan pengumpul data. Data yang diperoleh dianalisis secara kuantitatif dan hasilnya dikategorikan berdasarkan simpangan baku ideal. Hasil yang diperoleh dalam kegiatan ini adalah kemampuan guru-guru di SMK Negeri 1 Sota dalam menfaatkan TI untuk mendukung proses pembelajaran masih kurang.
\end{abstract}

Kata Kunci: media pembelajaran online, kemampuan pedagogik, google classroom, google form

\section{Pendahuluan}

Guru merupakan pekerjaan yang profesional. Hal ini dikarenakan guru merupakan profesi yang penting dalam menciptakan sumber daya manusia yang berkompeten. Sesuai dengan Undangundang Nomor 14 Tahun 2005 diamanatkan bahwa guru merupakan profesi tenaga profesional yang mempunyai fungsi, peran, dan kedudukan yang sangat penting dalam mempersiapkan sumber daya manusia (SDM). Guru sebagai tenaga profesional berarti bahwa pekerjaan guru hanya dapat dilakukan oleh seseorang yang memiliki kualifikasi akademik, 
kompetensi dan sertifikat pendidik. Oleh karena itu, guru harus terus belajar, mengembangkan kompetensinya serta mampu beradaptasi dengan perkembangan teknologi informasi.

Pengembangan kompetensi guru sangatlah penting dikarenakan guru merupakan agen pembelajar. Hal ini sesuai dengan Peraturan Pemerintah Nomor 19 tahun 2005 berkaitan dengan Standar Nasional Pendidikan yang menjelaskan bahwa pendidik (guru) harus memiliki kualifikasi akademik dan kompetensi sebagai agen pembelajar, sehat jasmani dan rohani, serta memiliki kemampuan untuk mewujudkan tujuan pendidikan nasional. Kompetensi yang harus dimiliki guru diantaranya: (1) kompetensi kepribadian, (2) kompetensi pedagogik, (3) kompetensi sosial, dan (4) kompetensi profesional. Kompetensi guru untuk mengelola pembelajaran (kompetensi pedagogik) merupakan hal yang utama karena merupakan kompetensi yang membedakan guru dengan profesi lainnya. Oleh karena itu dalam kegiatan ini difokuskan pada peningkatan kompetensi pedagogik guru tanpa mengabaikan kompetensikompetensi lainnya.

Pedagogik diartikan sebagai ilmu yang berkaitan dengan pendidikan dimana ruang lingkupnya terbatas pada interaksi antara guru dan peserta didik (Widiarsa, Marhaeni, \& Sutama, 2013). Kompetensi pedagogik merupakan sejumlah kemampuan yang berkaitan dengan ilmu dan seni dalam mengajar (Saudagar \& Idrus, 2009). Aspek yang merupakan bagian dari kompetensi pedagogik meliputi pemahaman wawasan atau landasan pendidikan, pemahaman terhadap peserta didik, pengembangan terhadap kurikulum, perencanaan pembelajaran, pelaksanaan pembelajaran yang mendidik dan dialogis, pemanfaatan teknologi pembelajaran, evaluasi hasil belajar dan pengembangan peserta didik untuk mengaktualisasikan berbagai potensi yang dimilikinya (Mulyasa, 2011). Jika dikaitkan dengan tuntutan pendidikan di abad 21, maka penguasaan teknologi merupakan kompetensi yang harus dikuasai oleh seorang guru (Destiana \& Utami, 2017). Oleh karena itu, diperlukan aspek pemanfaatan teknologi dalam kompetensi pedagogik guru.

Teknologi yang dapat dimanfaatkan dalam bidang pendidikan yakni fasilitas yang disediakan oleh Google seperti Google Form dan Google Classroom. Google Form merupakan aplikasi yang dapat digunakan untuk membuat kuis, form dan survei online (Batubara, 2016). Fungsi Google Form dalam dunia pendidikan yakni untuk: (1) memberikan tugas atau ujian secara online, (2) mengumpulkan pendapat orang lain secara online, mengumpulkan berbagai data secara online, (4) membuat formulir pendaftaran online untuk sekolah, dan (5) membagikan kuesioner secara online (Batubara, 2016). Google Classroom merupakan sebuah aplikasi yang dirancang untuk mempermudah interaksi antara pendidik dan peserta didik dalam dunia maya (Albatani \& Razak, 2018). Google classroom dapat dimanfaatkan untuk memberikan tugas mandiri dan membuka ruang diskusi secara online (Savitri, 2019).

Dosen merupakan sakah salah satu penanggung jawab dalam dunia pendidikan sehingga memiliki kewajiban untuk membantu dalam peningkatan kompetensi para guru. Salah satu bentuk upayanya adalah melakukan pelatihan sebagai bentuk pengabdian kepada masyarakat. Rencana strategis pengadian kepada masyarakat dapat dilakukan dalam bidang rekayasa teknologi yang mendukung pembangunan sektor industri, pertanian, dan kelautan yang berkelanjutan. Penjabaran rencana ini dapat dilaksanakan melalui aplikasi 
teknologi untuk pengembangan kampung-kampung sesuai potensi daerah dan lokal di Kabupaten Merauke dan sekitarnya (pembangunan pada tiga sektor utama) (LPPM Unmus, 2016). Salah satu daerah yang harus dikembangkan di Kabupaten Merauke adalah Sota karena berada di daerah perbatasan, yaitu daerah terdepan dan terluar yang berbatasan langsung dengan daratan negara lain (Bappenas, 2014). Pengembangan daerah perbatasan sangatlah penting. Ada banyak alasan mengapa daerah perbatasan penting untuk dikembangkan. Kasus yang terjadi di kawasan perbatasan negara seperti di klaimnya Sipadan-Ligitan oleh Malaysia serta konflik horisontal merupakan beberpa contoh yang menjadi alasan pemerataan pembangunan (Kemdikbud, 2016).

Sekolah Menengah Kejuruan (SMK) Negeri 1 Sota merupakan sekolah yang terletak di Sota, Kecamatan Sota, Kabupaten Merauke. Sekolah ini berjarak $79 \mathrm{~km}$ dari kota Merauke atau sekitar $1 \mathrm{~km}$ dari gerbang perbatasan Negara Kesatuan Repubik Indonesia (NKRI) dan Papua New Guinea (PNG). SMK Negeri 1 Sota merupakan satusatunya sekolah jenjang menengah atas di Kecamatan Sota. Peserta didik SMK Negeri 1 Sota terdiri dari warga asli Papua, warga pendatang dari luar Papua, serta warga dari negara tetangga, PNG. Peserta didik SMKN 1 Sota pada tahun ajaran 2018/2019 berjumlah 118 orang yang terdiri atas 83 laki-laki dan 35 perempuan. Jumlah rombongan kelas di sekolah ini ada 6 yang diselenggarakan pada pagi hari. SMKN 1 Sota mempunyai guru berjumlah 18 orang (Kemdikbud, 2018).

Berdasarkan paparan di atas, maka sangat penting dilakukan pelatihan kepada guru-guru SMK Negeri 1 Sota dalam menggunakan berbagai aplikasi teknologi informasi dan data dari hasil akhir pelatihan ini akan menjadi gambaran kemampuan pedagogik guru dalam Memanfaatkan Fasilitas Google untuk pembelajaran.

\section{Metode}

Kegiatan Pengabdian Kepada Masyarakat (PKM) ini dilakukan dalam bentuk pelatihan pemanfaatan fasilitas Google untuk pembelajaran. Adapun bentuk pelatihan dalam kegiatan ini dilakukan melalui pendampingan. Peserta pelatihan berjumlah 19 orang yang terdiri atas guru, pemateri, dan mahasiswa. Pelaksanaan pelatihan dilaksanakan di ruangan laboratorium komputer SMK Negeri 1 Sota dengan tujuan untuk memperkenalkan beberapa aplikasi teknologi informasi dan komunikasi (TIK) dengan menggunakan PowerPoint sebagai media presentasi. Setelah itu, dilakukan pemetaan tentang aplikasi yang dapat digunakan oleh guru dalam pembelajaran. Hasil pemetaan pengetahuan teknologi (technological knowledge) ini menjadi dasar untuk mendesain/merancang modul pembelajaran sesuai kebutuhan guru sehingga penggunaannya lebih efektif, praktis dan efisien.

$$
\text { Untuk mengetahui tingkat }
$$
kemampuan pedagogik guru SMK Negeri 1 Sota dalam pemanfaatan teknologi pembelajaran maka diberikan instrumen berupa angket kompetensi pedagogik yang dikhususkan pada aspek pemanfaatan teknologi pembelajaran. Angket ini terdiri dari tiga indikator yakni kemampuan menggunakan berbagai aplikasi TI, menggunakan Google Classroom dan Google Form. Terdapat 30 pernyataan yang dimuat dalam angket penilaian. Tiga puluh pernyataan tersebut terbagi menjadi 3 aspek, dimana masing-masing aspek memuat 10 pernyataan. Skala penilaian yang digunakan pada angket berupa skala likert dan dianalisis menggunakan simpangan baku ideal. Klasifikasi nilai simpangan baku ideal (Widoyoko, 2009) 
sesuai dengan banyaknya pernyataan pada angket penilaian disajikan pada Tabel 1 dan Tabel 2. Tabel 1 merupakan pengkategorian nilai per aspek sedangkan Tabel 2 adalah pengkategorian secara keseluruhan.

Tabel 1. Klasifikasi nilai simpangan baku ideal per aspek (Sbi)

\begin{tabular}{|l|l|c|}
\hline \multicolumn{1}{|c|}{ Rumus } & $\begin{array}{c}\text { Rerata } \\
\text { Skor }\end{array}$ & Klasifikasi \\
\hline$X$ & $X$ & \\
$>\bar{X}_{i}$ & & Sangat Baik \\
$+1.8 \times S b_{i}$ & $>42,6$ & \\
\hline $\bar{X}_{i}$ & & \\
$+0.6 \times S b_{i}$ & 34,2 & \\
$<X$ & $<X$ & Baik \\
$\leq \bar{X}_{i}$ & $\leq 42,6$ & \\
$+1.8 \times S b_{i}$ & & \\
\hline $\bar{X}_{i}$ & & \\
$-0.6 \times S b_{i}$ & 25,8 & \\
$<X$ & $<X$ & Cukup \\
$\leq \bar{X}_{i}$ & $\leq 34,2$ & \\
$+0.6 \times S b_{i}$ & & \\
\hline $\bar{X}_{i}$ & & \\
$-1.8 \times S b_{i}$ & 17,4 & \\
$<X$ & $<X$ & Kurang \\
$\leq \bar{X}_{i}$ & $\leq 25,8$ & \\
$-0.6 \times S b_{i}$ & & \\
\hline$X$ & $X$ & Sangat \\
$\leq \bar{X}_{i}$ & $\leq 17,4$ & Kurang \\
$-1.8 \times S b_{i}$ & $\leq 17$ \\
\hline
\end{tabular}

Tabel 2. Klasifikasi nilai simpangan baku ideal keseluruhan $\left(\mathrm{Sb}_{\mathbf{i}}\right)$

\begin{tabular}{|l|l|c|}
\hline \multicolumn{1}{|c|}{ Rumus } & $\begin{array}{c}\text { Rerata } \\
\text { Skor }\end{array}$ & Klasifikasi \\
\hline$X$ & $X$ & \\
$>\bar{X}_{i}$ & $>126$ & Sangat Baik \\
$+1.8 \times S b_{i}$ & & \\
\hline $\bar{X}_{i}$ & & \\
$+0.6 \times S b_{i}$ & 120 & \\
$<X$ & $<X$ & Baik \\
$\leq \bar{X}_{i}$ & $\leq 126$ & \\
$+1.8 \times S b_{i}$ & & \\
\hline
\end{tabular}

\begin{tabular}{|l|l|l|}
\hline $\bar{X}_{i}$ & & \\
$-0.6 \times S b_{i}$ & $78<X$ & \\
$<X$ & $\leq 102$ & Cukup \\
$\leq \bar{X}_{i}$ & & \\
$+0.6 \times S b_{i}$ & & \\
\hline $\bar{X}_{i}$ & & \\
$-1.8 \times S b_{i}$ & $54<X$ & Kurang \\
$<X$ & $\leq 78$ & \\
$\leq \bar{X}_{i}$ & & \\
$-0.6 \times S b_{i}$ & & Sangat \\
\hline$X$ & & Kurang \\
$\leq \bar{X}_{i}$ & $X \leq 54$ & \\
$-1.8 \times S b_{i}$ & & \\
\hline
\end{tabular}

Variabel $X$ pada tabel di atas merupakan rerata skor empiris yang diperoleh dari angket penilaian. Variabel $\bar{X}_{i}$ merupakan rerata ideal, dan $S b_{i}$ merupakan simpangan baku ideal.

\section{Hasil dan Pembahasan}

Komponen pedagogik dalam pelatihan ini difokuskanpada tiga aspek yaitu kemampuan memadukan berbagai aplikasi TI, kemampuan menggunakan Google Classroom dan kemampuan menggunakan Google Form. Aspek kemampuan pertama adalah memadukan berbagai aplikasi teknologi informasi berkaitan dengan kemampuan dalam menggunakan slide presentasi, pengeras suara, aplikasi android, media sosial, komputer, hingga jaringan internet dalam mendukung kegiatan belajar mengajar. Aspek kemampuan kedua berkaitan dengan kemampuan menggunakan google classroom untuk terhubung dengan siswa melalui pemberian materi, tugas mandiri, hingga berdiskusi. Aspek kemampuan ketiga berkaitan dengan kemampuan dalam mencari sumber-sumber ilmiah untuk menjadi referensi belajar. 


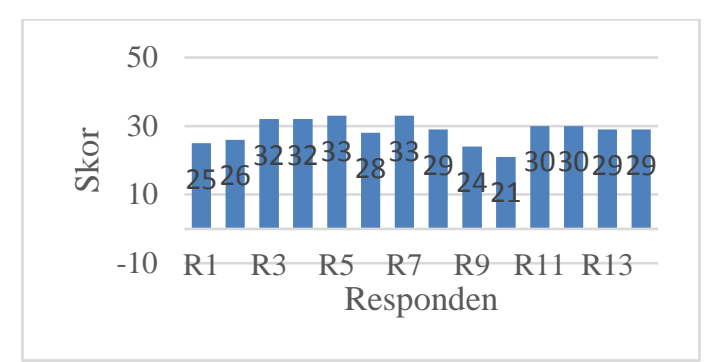

Gambar 1. Diagram Kemampuan Pedagogik Guru (Aspek Pertama)

Gambar 1 menunjukkan kemampuan pedagogik guru terkait penggunaan berbagai aplikasi TI. Skor yang didapat pada aspek ini dikonsultasikan dengan pengklasifikasian pada Tabel 1. Pada aspek pertama ini, terdapat 11 responden yang memiliki klasifikasi kemampuan "cukup" dan 3 responden yang klasifikasi kemampuannya "kurang" dalam menggunakan aplikasi TI. Hasil angket memperlihatkan bahwa beberapa guru sudah familiar dengan program Microsoft powerpoint untuk menyampaikan materi, memanfaatkan video untuk memberikan ilustrasi atau simulasi di kelas, menggunakan komputer untuk membuat materi pelajaran, serta terhubung ke internet melalui wifi. Akan tetapi, para responden tersebut hampir tidak pernah sama sekali memanfaatkan smartphone dalam kegiatan pembelajaran. Misalnya untuk berkomunikasi dengan siswa melalui aplikasi, ujian secara online, serta mengumpulkan tugas melalui email. Artinya, teknologi TI yang dimanfaatkan para responden baru sebatas program pada komputer saja dan belum mencapai program pada smartphone.

Aspek kedua adalah pemanfaatan media pembelajaran online. Pada aspek ini hanya terdapat dua responden saja yang mengetahui dan dapat menggunakannya untuk memfasilitasi proses belajar siswa. Padahal dari segi efektivitas, media pembelajaran online dapat mempermudah tugas guru dalam menyampaikan materi karena dapat mengirim file ke siswa dan melakukan tanya jawab melalui jaringan internet dengan mereka. Secara keseluruhan, pada aspek ini terdapat enam responden yang berkemampuan "cukup" dan enam orang lainnya berkemampuan "kurang". Rincian skor responden dapat dilihat pada Gambar 2.

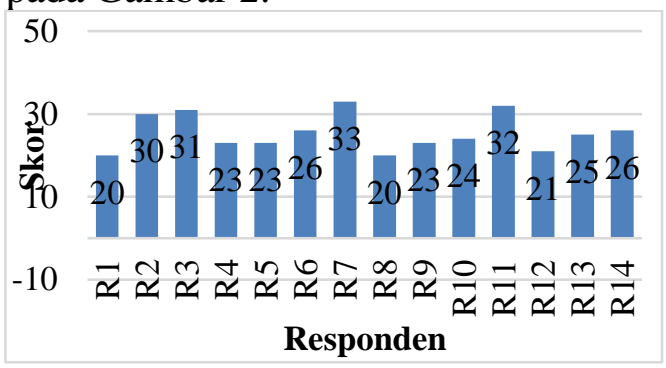

Gambar 2. Diagram Kemampuan Pedagogik Guru Aspek Kedua

Aspek ketiga merupakan aspek kemampuan guru terkait dengan pencarian data, informasi, buku, hingga jurnal melalui google form, perpustakan online, atau situs pencarian lainnya. Hasil angket mengungkapkan bahwa para responden tidak terbiasa mengakses database elektronik untuk mencari buku atau jurnal. Selain itu, hanya beberapa guru yang terampil dalam menyisipkan simbol, persamaan matematika, atau objek ke dalam dokumen. Pada aspek ini, hanya ada empat responden saja yang berkemampuan "cukup", sedangkan sisanya memiliki kemampuan "kurang" sebagaimana yang terlihat pada Gambar 3.

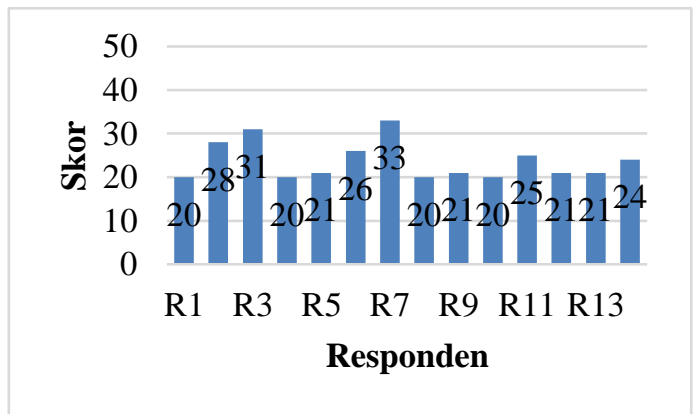

\section{Gambar 3. Diagram Kemampuan Pedagogik Guru Aspek Ketiga}




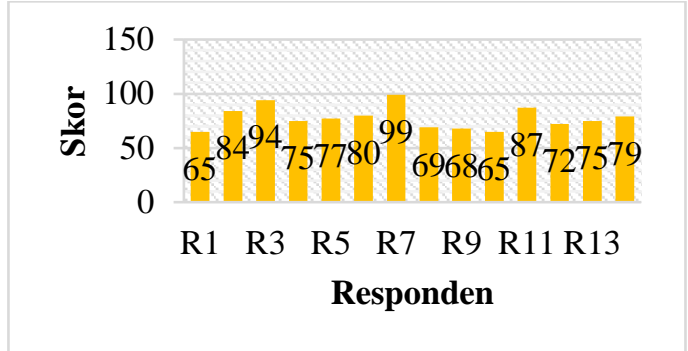

Gambar 4. Grafik kemampuan pedagogik guru

Gambar 4 memperlihatkan grafik dari kemampuan pedagogik guru dalam memanfaatkan fasilitas Google yang secara keseluruhan memiliki rerata 78 , atau dengan kata lain kemampuan guruguru secara umum masih berklasifikasi "kurang". Hanya ada 6 guru saja yang berkemampuan cukup dalam menggunakan TI untuk belajar dan mengajar. Pemanfaatan teknologi di dalam pembelajaran merupakan salah satu aspek yang paling penting untuk dimiliki oleh seorang guru pada era pendidikan saat ini. Hal ini dikarenakan karakteristik peserta didik yang telah melek internet, aktif, dan dapat belajar dari berbagai sumber. Kemampuan TIK dasar guru terdiri dari empat komponen, yaitu pengoperasian komputer (hardware), penggunaan program aplikasi (software), penggunaan internet, dan pemanfaatan mesin pencarian untuk mencari informasi spesifik (Batubara, 2016). Para responden pada penelitian ini cukup familiar dengan penggunaan hardware, akan tetapi mereka belum mampu memanfaatkan internet dan laman web secara maksimal. Padahal kemampuan tersebut, baru sebatas kemampuan dasar.

Rendahnya kemampuan guru dalam bidang TI ini dapat menjadi masukan bagi pemerintah dalam mengambil kebijakan yang diperlukan dalam peningkatan kompetensi guru. Secara spesifik, guru-guru memerlukan pelatihan terkait blended learning, yaitu pendekatan pembelajaran yang menggabungkan pembelajaran tatap muka dan pembelajaran daring. Blended learning memerlukan media tertentu yang memungkinkan guru dan siswa tetap terhubung melalui jaringan internet.

\section{Kesimpulan dan Saran}

Kemampuan dalam menggunakan TIK dalam pembelajaran merupakan kompetensi yang diperlukan dalam menghadapi pembelajaran abad 21. Hasil yang diperoleh setelah dilakukan pelatihan menunjukkan bahwa kompetensi guru SMK Negeri 1 Sota dalam memanfaatkan TIK untuk kegiatan belajar mengajar masih tergolong kurang. Oleh karena itu, dibutuhkan proses pembiasaan dalam memanfaatkan TIK untuk kegiatan pembelajaran agar guru-guru semakin terlatih.

\section{DAFTAR PUSTAKA}

Albatani, \& Razak. (2018). Desain Perkuliahan Bahasa Arab Melalui Google Classroom. Arabiyat: Jurnal Pendidikan Bahasa Arab Dan Kebahasaaraban, 5(1), 83-102.

Bappenas. (2014). Laporan Akhir:

Kajian Evaluasi Program Pembangunan dan Pengembangan Kawasan Khusus dan Daerah Tertinggal. Jakarta.

Batubara, H. H. (2016). Penggunaan Google Form sebagai Alat Penilaian Kinerja Dosen di Prodi PGMI Uniska Muhammad Arsyad Al Banjari. AL-BIDAYAH: Jurnal Pendidikan Dasar Islam, 8(1), 4050. Retrieved from https://jurnal.albidayah.id/index.php /home/article/view/91/88

Destiana, B., \& Utami, P. (2017). Urgensi Kompetensi Pedagogik Guru Vokasional. Elinvo (Electronics, Informatics, and Vocational Education), 2(2), 211222. 
https://doi.org/https://doi.org/10.102 1/ja00724a013

Kemdikbud. (2016). Analisis Sebaran Guru Dikdasmen di Wilayah $3 T$ (Terluar, Terdepan, dan Tertinggal) Tinjauan Sekolah Menengah Pertama. Jakarta: Pusat Data dan Statistik Pendidikan dan Kebudayaan, Kementerian Pendidikan dan Kebudayaan.

Kemdikbud. (2018). Data Pokok Pendidik Dasar dan Menengah Kementerian Pendidikan dan Kebudayaan. Retrieved April 12, 2018, from dapo.dikdasmen.kemdikbud.go.od/s ekolah/ A3D9B8FDE3D04F4BAC44

LPPM Unmus. (2016). Rencana Strategis Pengabdian Kepada Masyarakat. Merauke: Lembaga Penelitian dan Pengabdian Kepada Masyarakat Universitas Musamus.

Mulyasa. (2011). Standar Kompetensi dan Sertifikasi Guru. Bandung: PT Remaja Rosdakarya.

Saudagar, F., \& Idrus, A. (2009). Pengembangan Profesionalitas Guru. Jakarta: Gaung Persada Press.

Savitri, D. I. (2019). Penggunaan Pembelajaran 4.0 Berbantuan Aplikasi Google Classroom dan Google Form dalam Mata Kuliah Ilmu Sosial Budaya Dasar. Jurnal Borneo Saintek, 2(1), 20-25. https://doi.org/https://doi.org/10.101 7/CBO9781107415324.004

Widiarsa, I. G. P., Marhaeni, A. A. A. I. N., \& Sutama, I. M. (2013). Kontribusi Kompetensi Pedagogik dan Kompetensi Profesional Terhadap Hasil Belajar IPS (Studi Persepsi Pada Guru SD Kecamatan Kerambitan). Jurnal Pendidikan Dasar Ganesha, 3(1).

Widoyoko, E. P. (2009). Evaluasi program pembelajaran (S. Z. Qudsy, Ed.). Yogyakarta: Pustaka Pelajar. 